\title{
RELEVANCE OF THE CIPPO MODEL IN THE EVALUATION OF INDUSTRIAL WORK PRACTICES PROGRAMS IN INTEGRATED ISLAMIC VOCATIONAL SCHOOL
}

\author{
Nur Anisah ${ }^{1}$ \\ Sekolah Islam Terpadu Fitrah Hanniah \\ Bekasi
}

\section{Dinny Devi Triana ${ }^{2}$ \\ Universitas Negeri Jakarta}

Anan Sutisna ${ }^{3}$

Universitas Negeri Jakarta

Erwin Sulaeman ${ }^{4}$

Universitas Negeri Jakarta

\author{
Address for Correspondence: \\ ${ }^{1}$ NurAnisah_9912818005@mhs.unj.ac.id \\ 2dinnydevitriana@unj.ac.id \\ 3asutisna@unj.ac.id
}

\section{ABSTRACT}

The objective of this study is to investigate the implementation effectivity of the Ma'had alJamiah Program in IAIN Sulthan Thaha Saifuddin Jambi. The design of the study is the evaluative survey by applying CIPP and DEM evaluation models. In this research, the evaluation result level is devided into five categories, that are: very good, good, moderate, fair, and not applicative program. The result of the study is Ma'had alJamiah Program included in moderate category. Some reasons for stating the program included in this category are the college does not have any permanent clasrooms, students' desks and chairs, library, book references, and mosque. Ma'had alJamiah does not have specific curriculum in learning process program. Most of the lecturers do not make learning plan. They do not evaluate students' learning performance, both theory and application in the way of doing practice worship. Based on the results of the study it is recommended to the leaders of Al-Jami'ah Ma'had to fulfil infrastructure the college and remind the lecturers to prepare lesson plans and carry out the evaluation of both theory and application in the way of doing practice worship learning.

\section{Keywords}

program evaluation, Ma'had alJamiah, cipp and dem models

\section{INTRODUCTION}

Useful industrial work practices provide valuable practical experiences to broaden the knowledge of students. A high work attitude can also be had in the implementation of industrial work practices as well as motivation in improving the work ethic of students as graduates of Vocational High School (Aferi, 2019). Motivation and the creation of a work culture culture in schools will help students have readiness to enter the world of industry or the world of work (Adams et al., 2017).

In the era of transformation of the current 4.0 industrial revolution system there are five impact clusters, namely: on the field 1) Economy: growth, employment and the nature of work, 2) Business: consumer expectations, better data products, collaborative innovation and new operations research, 3) National-Global Relations: 
governance; Country, Region and city; national security, 4) Public; inequality and middle class, community, 5) Individual; identity, ethical morality; human connections, public and private management (Nugraha, 2019). These five things are the foundation that must be built firmly in anticipation of the impact of the transformation of the industrial revolution era 4.0. In facing economic, social and cultural openness among countries globally, especially in the implementation of the Asean Economic Community (AEC) which took effect at the end of 2015, Indonesia is faced with increasingly fierce competition, including in the provision of workers who will fill the need for labor in the fields of industry, trade, tourism and other jobs in MEA member countries (Ferguson, 2014). If Indonesia does not prepare to provide skilled, intermediate, to professional workforce, starting from improving access and quality of secondary education, It is certain that Indonesia will only become a shelter for skilled workers, intermediate to professional from MEA member countries (Rohman \& Ningsih, 2018).

Facts based on data published by the Central Statistics Agency in August 2016 show that the employment structure in Indonesia had based on graduates. The workforce that comes from junior high school graduates and below is $60.24 \%$, while the workforce originating from secondary education graduates was $27.12 \%$, and workers who come from college graduates by 12.24\% (Adam and Rahayu, 2019). Through Presidential Instruction (Inpres) Number 9 of 2016 concerning Revitalization of Vocational High Schools, The world of education, especially SMK had helped because it will create synergy between related agencies and institutions in accordance with their respective duties and functions in order to raise the quality of SMK. Public interest in pursuing vocational education is inseparable from the level of absorption of SMK graduates in the business world and in the industrial world (Andriani et al., 2020).

One of the government's policies on the implementation of vocational high schools or SMK in Indonesia is link and match (Bellová et al., 2018). Operationally, this link and match policy is expected to be able to change the supply driven approach to become demand driven, by involving the business world and industry to participate in the totality of planning, implementation, and evaluation of vocational education synergies between schools and DU / DI will determine the outcome of industrial work practice programs (Malik and Hasanah, 2019).

According to Garnett, one of the industrial work practice programs is the use of the world of work or the business world as a place of learning that offers added valued to educational institutions. Through developing interests in terms of partnerships and intellectual capital (Kamin et al., 2014) . The results of industrial work practice can be viewed from the mental psychological perspective (Rahdiyanta, 2019). The stages of industrial work practice activities will affect the objectives of industrial work practice. To determine the level of achievement of the results of the industrial work practice program, evaluation is needed (Anugerah and Daryati, 2017). The mental readiness of students will affect the results of industrial work practices (Skriner et al., 2017).

According to Prosser, vocational education will be more effective if it is able to change individuals according to attention, the nature and level of intelligence at the highest possible level, it means that after conducting education and training (diklat) the trainees improve their skills (Ardi, 2019). Prosser is known for his principles in vocational education, including: (1) Vocational education will be efficient if the environment in which students are trained is a replica of the environment in which they will work later. (2) Effective vocational education can only be provided where the training tasks are carried out in the same manner, tools and machines as those prescribed in the workplace. (3) Vocational education will be effective if it trains a 
person in the habits of thinking and working as required in the job itself. (4) Vocational education will be effective if the training experience to form work habits and correct thinking habits is repeated so that it fits what is needed in later work. (5) The process of developing habits that are effective in students will be achieved if the training is given in real work (value-laden experience). (6) A reliable source for knowing the content of training in a particular occupation is from the experience of these occupational experts (Iriani \& Soeharto, 2015)

The competition for vocational school graduates for employment is getting tighter because of the increase in the number of graduates who are not proportional to the growth in employment according to their expertise (Almomen et al., 2016). Integrated Islamic Vocational High School is a vocational high school that puts forward the concept educational research that combines the knowledge of qauli and qauni into one unit in learning so that it is expected that quality students will be born both academically and mentally and spiritually (Widiawati et al., 2018). The Indonesian Integrated Islamic School Network as the empowering center for integrated Islamic schools continues to strive to develop these schools into schools that have high quality standards with the uniqueness of Integrated Islamic Schools (Anugerah and Daryati, 2017).

Atkinson (2015) states that work-based learning and the inclusion of the world of work into student learning in the education system and on the job training traditional vocational training have been through apprenticeships. Has a strong focus on 'on-thejob' training, but also through training in 'work-oriented' institutions. The vocational education system must be able to respond quickly to technological changes according to the needs of the industrial world by continuing to evaluate and modify curriculum and partnership programs with the industrial world (Kamin et al., 2014).

The novelty in this study, seen from similar research, has the novelty of research respondents, namely students of Integrated Islamic Vocational Schools who have additional graduate competency standards and evaluate to the impact of students' absorption on DU / DI partners and changes in attitudes. Based on this, it is necessary to evaluate the program to find out the obstacles in the implementation of the program. Evaluation or assessment means the act of determining the value of something. In a broad sense, evaluation is a process of planning, obtaining, and providing information that is indispensable for making decision alternatives. One of the evaluation functions is as a measure of success, intended to determine the extent to which a program has been successfully implemented (Iriani \& Soeharto, 2015). Thus, based on the above explanation, this study aims to evaluate the implementation of industrial work practice programs in integrated Islamic vocational high schools with context, input, process, product and outcome approaches.

\section{METHOD}

The research approach used the CIPPO evaluation model developed by Stufelbeam. This research is descriptive quantitative in evaluating the implementation of industrial work practice programs at Integrated Islamic Vocational Schools, conducted to determine the relevance according to Context, Input, Process, Product and Outcome. This study measures the extent to which the appropriateness of industrial work practice programs is in line with the expectations of schools and the industrial world. Looking at research data with predetermined research criteria in order to obtain information that will be used as material for further consideration, 
recommendations and policy making for the advancement of industrial work practice programs at Integrated Islamic Vocational Schools.

The research location of the Integrated Islamic Vocational School Fitrah Hanniah Bekasi. The data collection method was carried out by giving a questionnaire, with a sample of 73 students from three majors and class XII with a total of 60 students from three majors, namely TSM, TPMI and Accounting with a total of 133 students who have participated in the industrial work practice program, four teachers who supervise industrial work practice programs, two deputy head of industrial relations, one deputy head of curriculum and one principal.

\section{RESULT}

This research was conducted to identify the suitability of the industrial work practice program by referring to the CIPPO model seen from five dimensions, namely the dimensions of Context, Input, Product Process and Outcome. Based on the data that has been obtained, an analysis of the data is carried out so that it can answer the existing problems. The details of the data processing are based on 5 dimensions, namely:

1. Evaluation of context, obtained the results of research on the objectives of industrial work practices program, student competence, work ethic, and link and match. Data from the response of the school and DU / DI:

Table 1 Statistical analysis of the response of the school and DU / DI

\begin{tabular}{|l|l|l|l|l|l|l|l|l|l|}
\hline \multirow{2}{*}{ No. } & \multirow{2}{*}{ Respondents } & \multicolumn{2}{|l|}{ Analyze the context dimension } \\
\cline { 3 - 11 } & & $\begin{array}{l}\text { Highest } \\
\text { Score }\end{array}$ & $\begin{array}{l}\text { Lowest } \\
\text { Score }\end{array}$ & Mi & Sdi & Mean & Median & SD & $\begin{array}{l}\text { Total } \\
\text { Score }\end{array}$ \\
\hline 1. & IA Principal & 70 & 14 & 42 & 9,3 & 4,071 & 4 & 0,27 & 57 \\
\hline 2. & IA Teachers & 70 & 14 & 42 & 9,3 & 61,75 & 59,5 & 4,86 & $59-69$ \\
\hline 3. & $\begin{array}{l}\text { IA deputy } \\
\text { head of } \\
\text { industrial } \\
\text { relations }\end{array}$ & 70 & 14 & 42 & 9,3 & 54,5 & 54,5 & 6,36 & $50-59$ \\
\hline 4. & $\begin{array}{l}\text { IA deputy } \\
\text { head of } \\
\text { curriculum }\end{array}$ & 70 & 14 & 42 & 9,3 & 4,5 & 4,5 & 0,52 & 63 \\
\hline
\end{tabular}

Note: Mi: The ideal mean; Sdi: Ideal standard deviation; Max: maximum value; Min: minimum value: SD: Standard Deviation

Table 2 Response categories of school and DU / DI

\begin{tabular}{|l|l|}
\hline Value Interval & Category \\
\hline$X>=51,3$ & Very Relevant / Very Good \\
\hline $42=<X<51,3$ & Relevant / Good \\
\hline $32,7=<X<42$ & Relevant Enough / Good Enough \\
\hline $23,4=<X<32,7$ & Irrelevant / Not Good \\
\hline$X<14,1$ & Very Irrelevant / Very Not Good \\
\hline$X:$ respondent score &
\end{tabular}

The total score indicated by the response from one principal is 57 in the interval $57>=51.3$ in the very relevant or very good category. The responses of the four teachers showed the total score was in the range 59 - 69 which was in the very relevant or very good category. Furthermore, the total score of the responses of the two deputy head of industrial relations was in the range 50 - 59 in the very relevant or very good 
category. Next, the response from one deputy head of curriculum showed a total score of 63 in the very relevant or very good category (Azwar, 2018).

Thus, based on the results of this explanation, it is known that the context dimension of the school and DU / DI response is in the very relevant or very good category. This shows that the context component with its indicators is very good in reviewing internship activities, In addition, the apprenticeship program through good planning and by adjusting the needs of students at the Integrated Islamic Vocational School. Student response data to the context evaluation were obtained:

Table 3 Statistical analysis of student responses on context dimensions

\begin{tabular}{|l|l|l|l|l|l|l|l|l|}
\hline \multirow{2}{*}{ Respondents } & \multicolumn{6}{|l|}{ Results of statistical analysis } \\
\cline { 2 - 9 } & Mean & Median & Modus & SD & Mi & Sdi & $\begin{array}{l}\text { Highest } \\
\text { Score }\end{array}$ & $\begin{array}{l}\text { Lowest } \\
\text { Score }\end{array}$ \\
\hline 133 students & 58,293 & 57 & 52 & 7,183 & 42 & 9,3 & 70 & 14 \\
\hline
\end{tabular}

Note: SD: Standard Deviation; Mi: The ideal mean; Sdi: Ideal standard deviation: Max: Maximum value; Min: Minimum value

Table 4 Student response categories in context dimensions

\begin{tabular}{|l|l|l|l|}
\hline Value Interval & Category & $\begin{array}{l}\text { Freq. } \\
\text { (f) }\end{array}$ & $\begin{array}{l}\text { Freq. Relative } \\
(\%)\end{array}$ \\
\hline$X>=51,3$ & Very Relevant / Very Good & 116 & $87 \%$ \\
\hline $42=<X<51,3$ & Relevant / Good & 15 & $11 \%$ \\
\hline $32,7=<X<42$ & $\begin{array}{l}\text { Relevant Enough / Good } \\
\text { Enough }\end{array}$ & 2 & $2 \%$ \\
\hline $23,4=<X<32,7$ & Irrelevant / Not Good & - & - \\
\hline$X<14,1$ & $\begin{array}{l}\text { Very Irrelevant / Very Not } \\
\text { Good }\end{array}$ & - & - \\
\hline
\end{tabular}

Figure 1 Student response graph in context dimension

The frequency value of 116 or $87 \%$ indicates that the responses from students are in the very relevant or very good category, while the frequency value is 15 or $11 \%$ in the relevant or good category, and the frequency values 2 or $2 \%$ are in the category of sufficiently relevant or good enough. The diagram shows that as many as 116 of the 133 student responses or $87 \%$ are in the category which states that the context

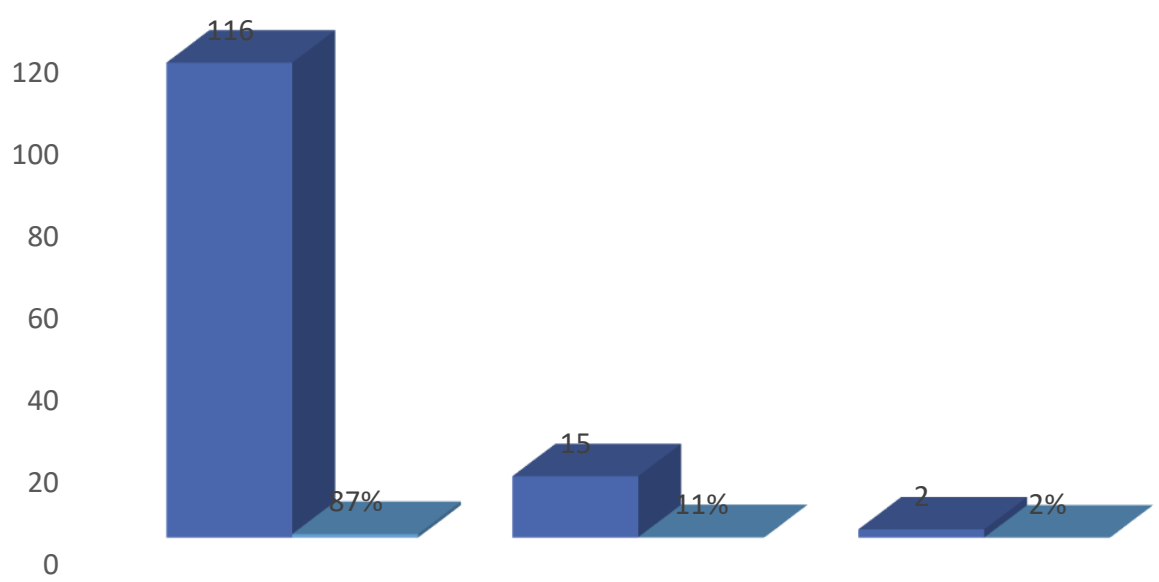

dimension is very relevant or very good. This can indicate that students' responses to 
the context dimension through statement items can directly represent the conditions perceived by students. Based on this explanation, it can be concluded that the student response to the components of the context dimension with the indicators is very good for reviewing internship activities.

2. Evaluation of Input, obtained the results of research on the components of planning, provisioning, curriculum, engineering, facilities and infrastructure, students, and financing. Data from the response of the school and DU / DI:

Table 5 Statistical analysis of the response of the school and DU / DI

\begin{tabular}{|c|c|c|c|c|c|c|c|c|c|}
\hline \multirow[b]{2}{*}{ No. } & \multirow[b]{2}{*}{ Respondents } & \multicolumn{8}{|c|}{ Analyze the input dimension } \\
\hline & & $\begin{array}{l}\text { Highest } \\
\text { Score }\end{array}$ & $\begin{array}{l}\text { Lowest } \\
\text { Score }\end{array}$ & Mi & Sdi & Mean & Median & SD & $\begin{array}{l}\text { Total } \\
\text { Score }\end{array}$ \\
\hline 1. & IA Principal & 100 & 20 & 60 & 13,3 & 4 & 4 & 0,32 & 80 \\
\hline 2. & IA Teachers & 100 & 20 & 60 & 13,3 & 82,75 & 71,5 & 7,59 & $75-93$ \\
\hline 3. & $\begin{array}{l}\text { IA deputy } \\
\text { head of } \\
\text { industrial } \\
\text { relations }\end{array}$ & 100 & 20 & 60 & 13,3 & 71 & 71 & 4,24 & $68-74$ \\
\hline 4. & $\begin{array}{l}\text { IA deputy } \\
\text { head of } \\
\text { curriculum }\end{array}$ & 100 & 20 & 60 & 13,3 & 4,2 & 4 & 0 & 84 \\
\hline
\end{tabular}

Note: Mi: The ideal mean; Sdi: Ideal standard deviation; Max: maximum value; Min: minimum value: SD: Standard Deviation

Table 6 Categories of school and DU / DI responses

\begin{tabular}{|l|l|}
\hline Value Interval & Category \\
\hline$X>=73,3$ & Very Relevant / Very Good \\
\hline $60=<X<73,3$ & Relevant / Good \\
\hline $46,7=<X<60$ & Relevant Enough / Good Enough \\
\hline $33,4=<X<46,7$ & Irrelevant / Not Good \\
\hline$X<20,1$ & Very Irrelevant / Very Not Good \\
\hline
\end{tabular}

The total score indicated by the response of one principal is 80 in the interval $80>=73.3$ in the very relevant or very good category. The responses of the four teachers showed that the total score was in the range $75-93$ which was in the very relevant or very good category. Furthermore, the total score of the responses of the two deputy head of industrial relations was in the range of $68-74$ in the very relevant or very good category. Next, the response from one deputy head of curriculum showed a total score of 84 in the very relevant or very good category.

Thus it can be concluded that the input dimension of the school and DU / DI response is in the very relevant or very good category. This shows that the input component with its indicators is very good in reviewing the internship activities at the Integrated Islamic Vocational School. Data on the results of students' responses to the input dimensions: 
Table 7 Statistical analysis of student responses on input dimensions

\begin{tabular}{|l|l|l|l|l|l|l|l|l|}
\hline \multirow{2}{*}{ Respondents } & \multicolumn{6}{|l|}{ Results of statistical analysis } \\
\cline { 2 - 8 } & Mean & Median & Modus & SD & Mi & Sdi & $\begin{array}{l}\text { Highest } \\
\text { Score }\end{array}$ & $\begin{array}{l}\text { Lowest } \\
\text { Score }\end{array}$ \\
\hline 133 students & 80,48 & 80 & 75 & 11,18 & 60 & 13,3 & 100 & 20 \\
\hline
\end{tabular}

Note: SD: Standard Deviation; Mi: The ideal mean; Sdi: Ideal standard deviation: Max: Maximum value; Min: Minimum value

Table 8 Categories of student responses on input dimensions

\begin{tabular}{|l|l|l|l|}
\hline Value Interval & Category & $\begin{array}{l}\text { Freq. } \\
\text { (f) }\end{array}$ & $\begin{array}{l}\text { Freq. } \\
\text { Relative } \\
(\%)\end{array}$ \\
\hline$X>=73,3$ & Very Relevant / Very Good & 100 & $75 \%$ \\
\hline $60=<X<73,3$ & Relevant / Good & 30 & $23 \%$ \\
\hline $46,7=<X<60$ & Relevant Enough / Good Enough & 3 & $2 \%$ \\
\hline $33,4=<<46,7$ & Irrelevant / Not Good & - & - \\
\hline$X<20,1$ & Very Irrelevant / Very Not Good & - & - \\
\hline
\end{tabular}

Figure 2 Student response graph in the input dimension

The frequency value of 100 or $75 \%$ indicates that the response from students is in the very relevant or very good category, while the frequency value of 30 or $23 \%$ is in the relevant or good category, and the frequency value of 3 or $2 \%$ is in the category of quite relevant or good enough. .

Student responses through the diagram illustrate that as many as 100 of the 133 student responses or $75 \%$ are in the category which states that the input

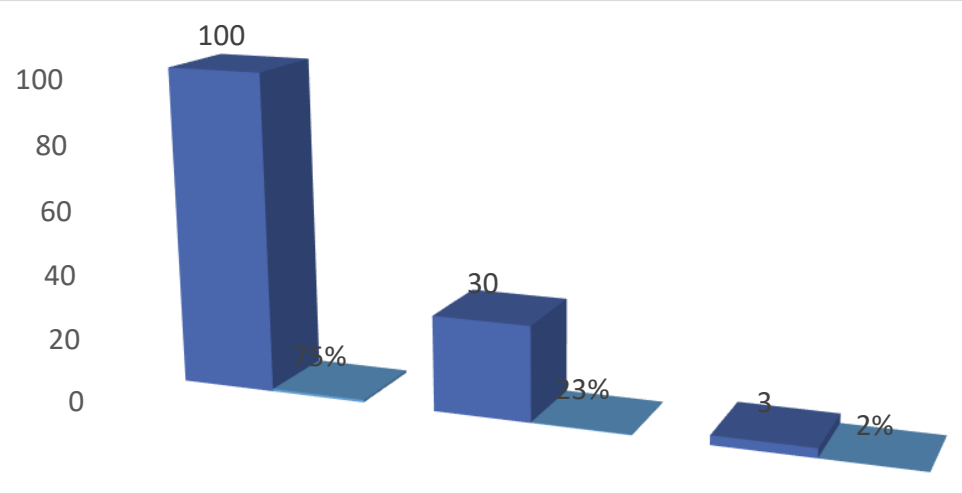

dimension is very relevant or very good. This can indicate that students' responses to the input dimension through statement items can directly represent the conditions perceived by students. Based on this explanation, it can be concluded that the student response to the input dimension component with the indicators is very good for reviewing internship activities.

3. Evaluation of the dimensions of the process obtained the results of the implementation component research, monitoring, effectiveness, school contributions, and mapping. Response data from the school and DU / DI in the process dimension: 
Table 9 Statistical analysis of the response of the school and DU / DI

\begin{tabular}{|l|l|l|l|l|l|l|l|l|l|}
\hline \multirow{2}{*}{ No. } & \multirow{2}{*}{ Respondents } & \multicolumn{2}{|l|}{ Analyze the process dimension } \\
\cline { 3 - 11 } & $\begin{array}{l}\text { Highest } \\
\text { Score }\end{array}$ & $\begin{array}{l}\text { Lowest } \\
\text { Score }\end{array}$ & Mi & Sdi & Mean & Median & SD & $\begin{array}{l}\text { Total } \\
\text { Score }\end{array}$ \\
\hline 1. & IA Principal & 50 & 10 & 30 & 6,6 & 4,1 & 4 & 0,32 & 81 \\
\hline 2. & IA Teachers & 50 & 10 & 30 & 6,6 & 53,75 & 53 & 5,90 & $48-61$ \\
\hline 3. & $\begin{array}{l}\text { IA deputy } \\
\text { head of } \\
\text { industrial of } \\
\text { relations }\end{array}$ & 50 & 10 & 30 & 6,6 & 37 & 37 & 0 & 74 \\
\hline 4. & $\begin{array}{l}\text { IA deputy } \\
\text { head of } \\
\text { curriculum }\end{array}$ & 50 & 10 & 30 & 6,6 & 3,6 & 3,6 & 1,17 & 36 \\
\hline
\end{tabular}

Note: Mi: Mean ideal; Sdi: Ideal standard deviation; Max: maximum value; Min: minimum value: SD: standard deviation

Table 10 Response categories of schools and DU / DI

\begin{tabular}{|l|l|}
\hline Value Interval & Category \\
\hline$X>=36,6$ & Very Relevant / Very Good \\
\hline $30=<X<36,6$ & Relevant / Good \\
\hline $23,4=<X<30$ & Relevant Enough / Good Enough \\
\hline $16,8=<X<23,4$ & Irrelevant / Not Good \\
\hline$X<10,2$ & Very Irrelevant / Very Not Good \\
\hline
\end{tabular}

The total score shown by the response of one principal is 81 in the interval $81>$ $=36.3$ in the very relevant or very good category. The responses of four teachers showed that the total score was in the range of $48-61$ in the very relevant or very good category. Furthermore, the total score of the responses of the two deputy head of industrial relations was in the range of 74 being in the very relevant or very good category. Next, the response from one deputy head of curriculum showed a total score of 36 in the relevant or good category.

Thus it can be concluded that the process dimension of the school and DU / DI response is in the very relevant or very good category. This shows that the process component with its indicators is very good in reviewing the internship activities at the Integrated Islamic Vocational School. Student Response Data on Process Dimensions:

Table 11 Statistical analysis of student responses on process dimensions

\begin{tabular}{|l|l|l|l|l|l|l|l|l|}
\hline \multirow{2}{*}{ Respondents } & \multicolumn{6}{|l|}{ Results of statistical analysis } \\
\cline { 2 - 9 } & Mean & Median & Modus & SD & Mi & Sdi & $\begin{array}{l}\text { Highest } \\
\text { Score }\end{array}$ & $\begin{array}{l}\text { Lowest } \\
\text { Score }\end{array}$ \\
\hline 133 students & 36,61 & 36 & 35 & 6,63 & 30 & 6,6 & 50 & 10 \\
\hline
\end{tabular}

Note: SD: Standard Deviation; Mi: The ideal mean; Sdi: Ideal standard deviation: Max: Maximum value; Min: Minimum value 


\begin{tabular}{|l|l|l|l|}
\hline Value Interval & Category & Freq. (f) & $\begin{array}{l}\text { Freq. } \\
\text { Relative (\%) }\end{array}$ \\
\hline$X>=36,6$ & Very Relevant / Very Good & 63 & $47 \%$ \\
\hline $30=<X<36,6$ & Relevant / Good & 55 & $41 \%$ \\
\hline $23,4=<X<30$ & $\begin{array}{l}\text { Relevant Enough / Good } \\
\text { Enough }\end{array}$ & 10 & $8 \%$ \\
\hline $16,8=<X<23,4$ & Irrelevant / Not Good & 5 & $4 \%$ \\
\hline$X<10,2$ & $\begin{array}{l}\text { Very Irrelevant / Very Not } \\
\text { Good }\end{array}$ & - \\
\hline
\end{tabular}

Table 12 Student response categories in process dimensions

Figure 3 student response diagram on process dimensions

The frequency value of 63 or $47 \%$ indicates that the responses from students are in the very relevant or very good category, while the frequency value of 55 or $41 \%$ is in the relevant or good category, and the frequency value of 10 or $8 \%$ is in the sufficiently relevant or good enough category, and the frequency value of 5 or about $4 \%$ is in the irrelevant or not good category. The illustration of the diagram illustrates that 63 out of 133 student responses or $47 \%$ are in the category which states that the

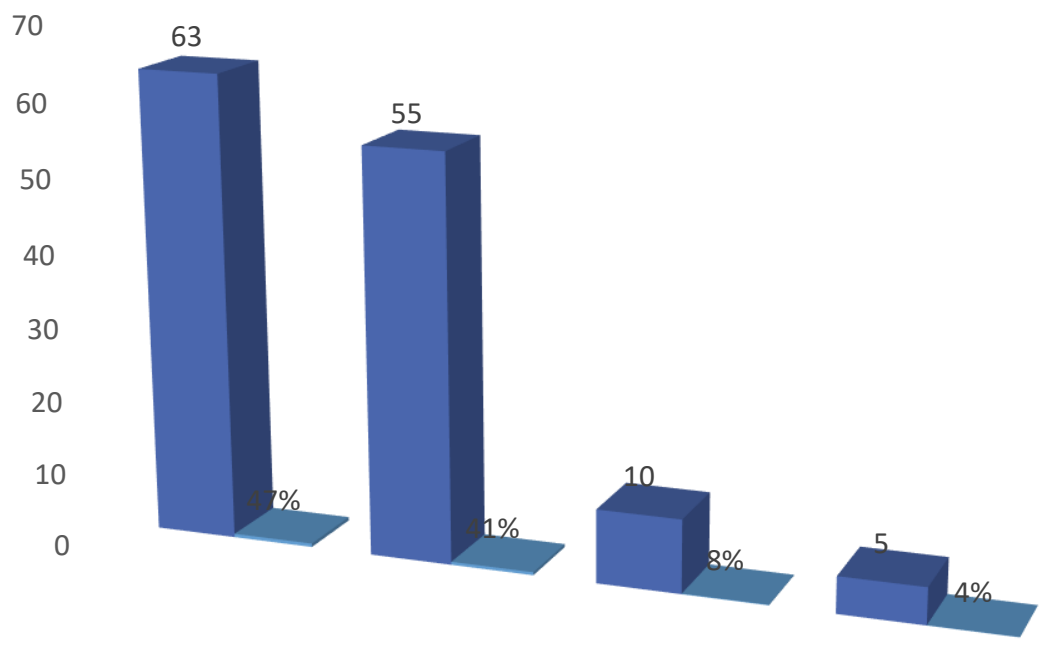

process dimension is very relevant or very good. This can indicate that students' responses to the process dimension through statement items can directly represent the conditions that students feel.

4. Evaluation of Product, the results of the research on the components of the competency test results and the DU / DI certification results are obtained. Response Data of Schools and DU / DI: 
Table 13 Statistical analysis of the response of the school and DU / DI

\begin{tabular}{|l|l|l|l|l|l|l|l|l|l|}
\hline \multirow{2}{*}{ No. } & Respondents & \multicolumn{2}{|l|}{ Analyze the product dimension } \\
\cline { 3 - 11 } & & $\begin{array}{l}\text { Highest } \\
\text { Score }\end{array}$ & $\begin{array}{l}\text { Lowest } \\
\text { Score }\end{array}$ & Mi & Sdi & Mean & Median & SD & $\begin{array}{l}\text { Total } \\
\text { Score }\end{array}$ \\
\hline 1. & IA Principal & 20 & 4 & 12 & 2,6 & 4 & 4 & 0 & 16 \\
\hline 2. & IA Teachers & 20 & 4 & 12 & 2,6 & 15,75 & 16 & 2,06 & $13-18$ \\
\hline & $\begin{array}{l}\text { IA deputy } \\
\text { head of } \\
\text { industrial } \\
\text { relations }\end{array}$ & 20 & 4 & 12 & 2,6 & 14,5 & 14,5 & 0,71 & $14-15$ \\
\hline 4. & $\begin{array}{l}\text { IA deputy } \\
\text { head of } \\
\text { curriculum }\end{array}$ & 20 & 4 & 12 & 2,6 & 4 & 4 & 0 & 16 \\
\hline
\end{tabular}

Note: Mi: Mean ideal; Sdi: Ideal standard deviation; Max: maximum value; Min: minimum value:

SD: standard deviation

Table 14 Response categories of school and DU / DI

\begin{tabular}{|l|l|}
\hline Value Interval & Category \\
\hline$X>=14,6$ & Very Relevant / Very Good \\
\hline $12=<X<14,6$ & Relevant / Good \\
\hline $9,4=<X<12$ & Relevant Enough / Good Enough \\
\hline $6,8=<X<9,4$ & Irrelevant / Not Good \\
\hline$X<4,2$ & Very Irrelevant / Very Not Good \\
\hline
\end{tabular}

The total score shown by the response of one principal is 16 in the interval 16> $=14.6$ in the very relevant or very good category. The responses of the four teachers showed that the total score was in the range $13-18$ in the very relevant or very good category. Furthermore, the total scores of the responses of the two deputy head of industrial relations were in the range of 14-15 in the very relevant or very good categories. Next, the response from one deputy head of curriculum showed a total score of 16 in the relevant or good category. It can be concluded that the product dimension of the school and DU / DI response is in the very relevant or very good category (Azwar, 2018). This shows that the product component with its indicators is very good in reviewing the internship activities at the Integrated Islamic Vocational School. Student response data on product dimensions:

Table 15 Statistical analysis of student responses on product dimensions

\begin{tabular}{|l|l|l|l|l|l|l|l|l|}
\hline \multirow{2}{*}{ Respondents } & \multicolumn{9}{|c|}{ Results of statistical analysis } \\
\cline { 2 - 9 } & Mean & Median & Modus & SD & Mi & Sdi & $\begin{array}{l}\text { Highest } \\
\text { Score }\end{array}$ & $\begin{array}{l}\text { Lowest } \\
\text { Score }\end{array}$ \\
\hline 133 students & 17,33 & 18 & 20 & 2,64 & 12 & 2,6 & 20 & 4 \\
\hline
\end{tabular}

Note: SD: Standard Deviation; Mi: The ideal mean; Sdi: Ideal standard deviation: Max: Maximum value; Min: Minimum value 


\begin{tabular}{|l|l|l|l|}
\hline Value Interval & Category & $\begin{array}{l}\text { Freq. } \\
(\mathrm{f})\end{array}$ & $\begin{array}{l}\text { Freq. } \\
\text { Relative } \\
(\%)\end{array}$ \\
\hline$X>=14,6$ & Very Relevant / Very Good & 113 & $85 \%$ \\
\hline $12=<X<14,6$ & Relevant / Good & 18 & $14 \%$ \\
\hline $9,4=<<12$ & Relevant Enough / Good Enough & 1 & $1 \%$ \\
\hline $6,8=<<<9,4$ & Irrelevant / Not Good & 1 & $1 \%$ \\
\hline$X<4,2$ & Very Irrelevant / Very Not Good & - & - \\
\hline
\end{tabular}

Table 16 Student response categories in product dimensions

Figure 4 Student response diagram on product dimensions

The frequency value 113 or $85 \%$ indicates that the student response is in the very relevant or very good category, while the frequency value is 18 or $14 \%$ in the relevant or good category, the frequency value of 1 or $1 \%$ is in the category of sufficiently relevant or good enough, and the frequency value of 1 or about $1 \%$ is in the irrelevant or not good category. Figure 4 is an illustration of the diagram illustrating

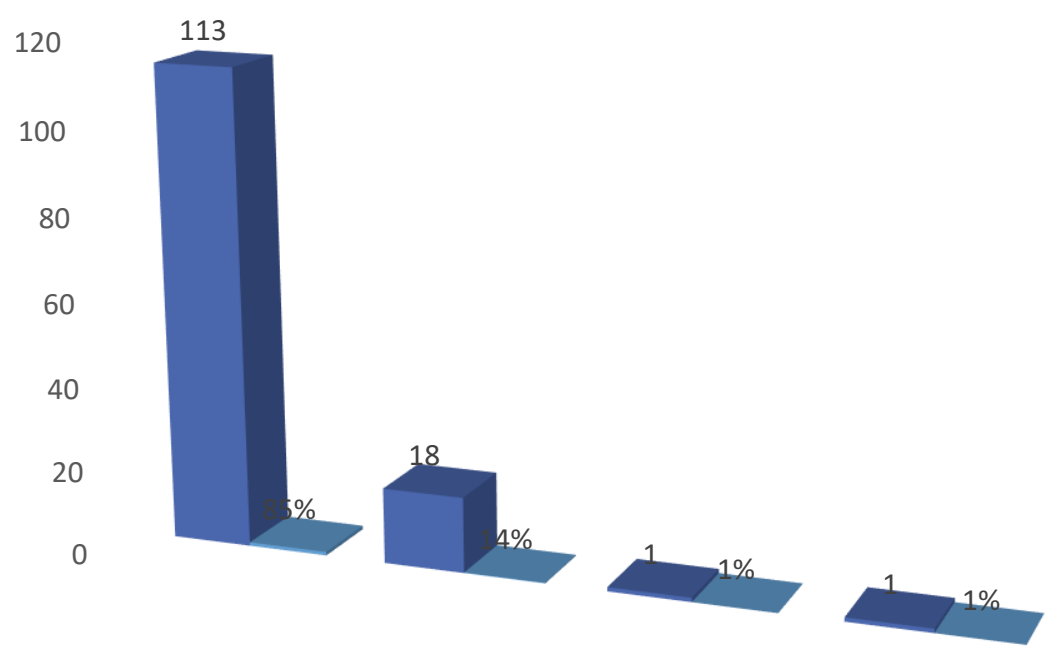

that 113 out of 133 student responses or $85 \%$ are in the category which states that the product dimensions are very relevant or very good. This can indicate that students' responses to the product dimension through statement items can directly represent the conditions felt by students.

5. Evaluation of Outcome, obtained the results of research on the components of the impact of absorption in DU / DI and changes in attitude skills. Response Data of Schools and DU / DI: 
Table 17 Statistical analysis of the response of the school and DU / DI

\begin{tabular}{|l|l|l|l|l|l|l|l|l|l|}
\hline No. & Respondents & \multicolumn{2}{|l|}{ Analyze the outcome dimension } \\
\cline { 3 - 11 } & $\begin{array}{l}\text { Highest } \\
\text { Score }\end{array}$ & $\begin{array}{l}\text { Lowest } \\
\text { Score }\end{array}$ & Mi & Sdi & Mean & Median & SD & $\begin{array}{l}\text { Total } \\
\text { Score }\end{array}$ \\
\hline 1. & IA Principal & 35 & 7 & 21 & 4,6 & 4 & 4 & 0 & 28 \\
\hline 2. & IA Teachers & 35 & 7 & 21 & 4,6 & 28,25 & 28 & 3,77 & $24-33$ \\
\hline & $\begin{array}{l}\text { IA deputy } \\
\text { head of } \\
\text { industrial } \\
\text { relations }\end{array}$ & 35 & 7 & 21 & 4,6 & 22,5 & 22,5 & 0,71 & $21-24$ \\
\hline 4. & $\begin{array}{l}\text { IA deputy } \\
\text { head of } \\
\text { curriculum }\end{array}$ & 35 & 7 & 21 & 4,6 & 4,28 & 4 & 0,49 & 30 \\
\hline
\end{tabular}

Note: Mi: Mean ideal; Sdi: Ideal standard deviation; Max: maximum value; Min: minimum value:

SD: standard deviation

Table 18 Response categories of school and DU / DI

\begin{tabular}{|l|l|}
\hline Value Interval & Category \\
\hline$X>=25,6$ & Very Relevant / Very Good \\
\hline $21=<X<25,6$ & Relevant / Good \\
\hline $16,4=<X<21$ & Relevant Enough / Good Enough \\
\hline $11,8=<X<16,4$ & Irrelevant / Not Good \\
\hline$X<7,2$ & Very Irrelevant / Very Not Good \\
\hline
\end{tabular}

The total score indicated by the response from one principal is 28 in the interval $28>=25.6$ in the very relevant or very good category. The responses of the four teachers showed that the total score was in the range of $24-33$ in the very relevant or very good category. Furthermore, the total score of the responses of the two deputy head of industrial relations was in the range 21-24 which was in the very relevant or very good category. Next, the response from one deputy head of curriculum showed a total score of 30 in the relevant or good category.

It can be concluded that the outcome dimension of the school and DU / DI response is in the very relevant or very good category. This shows that the outcome component with the indicators is very good in reviewing the internship activities at the Integrated Islamic Vocational School. Student Response Data on Outcome Dimensions:

Table 19 Statistical analysis of student responses on outcome dimensions

\begin{tabular}{|l|l|l|l|l|l|l|l|l|}
\hline \multirow{2}{*}{ Respondents } & \multicolumn{6}{|c|}{ Results of statistical analysis } \\
\cline { 2 - 9 } & Mean & Median & Modus & SD & Mi & Sdi & $\begin{array}{l}\text { Highest } \\
\text { Score }\end{array}$ & $\begin{array}{l}\text { Lowest } \\
\text { Score }\end{array}$ \\
\hline 133 students & 29,65 & 30 & 35 & 4,17 & 21 & 4,6 & 35 & 7 \\
\hline
\end{tabular}

Note: SD: Standard Deviation; Mi: The ideal mean; Sdi: Ideal standard deviation: Max: Maximum value; Min: Minimum value 
Table 20 Student response categories on outcome dimensions

\begin{tabular}{|l|l|l|l|}
\hline Value Interval & Category & $\begin{array}{l}\text { Freq. } \\
\text { (f) }\end{array}$ & $\begin{array}{l}\text { Freq. } \\
\text { Relative } \\
(\%)\end{array}$ \\
\hline$X>=25,6$ & Very Relevant / Very Good & 111 & $83 \%$ \\
\hline $21=<X<25,6$ & Relevant / Good & 18 & $14 \%$ \\
\hline $16,4=<X<21$ & Relevant Enough / Good Enough & 4 & $3 \%$ \\
\hline $11,8=<X<16,4$ & Irrelevant / Not Good & - & - \\
\hline$X<7,2$ & Very Irrelevant / Very Not Good & - & - \\
\hline
\end{tabular}

Figure 5 Student response diagram on outcome dimensions

The frequency value of 111 or $83 \%$ indicates that the student response is in the very relevant or very good category, while the frequency value was 18 or $14 \%$ in the relevant or good category, and the frequency value of 4 or $3 \%$ was in the sufficiently relevant or good enough category. The illustration in Figure 4.5 shows that 111 out of 133 student responses or $83 \%$ are in the category which states that the outcome dimension is very relevant or very good. This can indicate that students' responses to the outcome dimension through statement items can directly represent the conditions

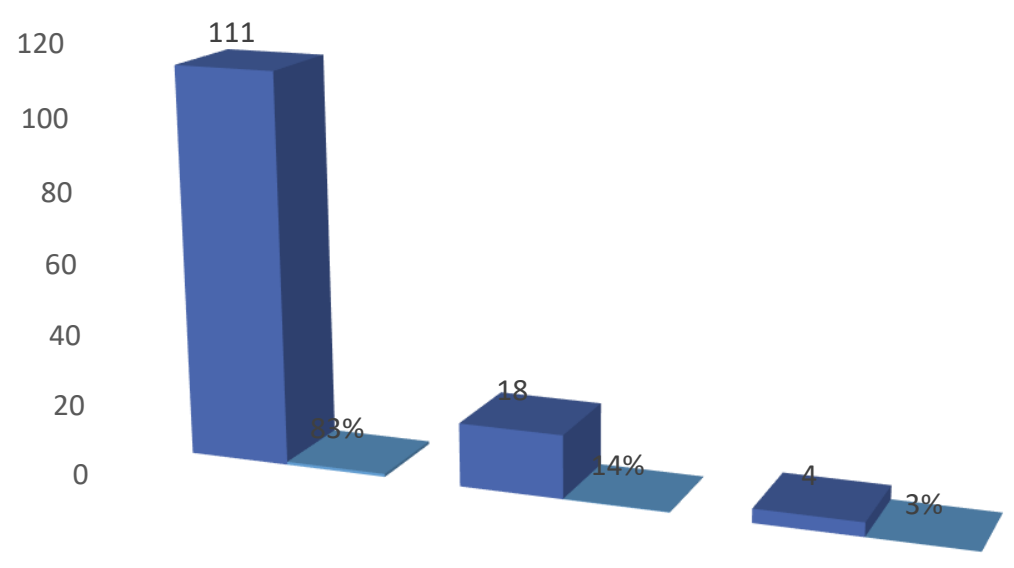

felt by students.

\section{CONCLUTION}

General conclusions from the results of the questionnaire circulated the implementation of the industrial work practice program in integrated Islamic SMK is good. In some items, in terms of the results of field observations, there is still a need for improvement and quality improvement in the system being implemented in order to lead to an increase in the quality of the implementation of industrial work practice programs. The industrial practice program is an educational activity, learning and training carried out by educational institutions and DU / DI pairs towards students with the aim of improving the quality of graduates of Integrated Islamic Vocational Schools according to their vocational competencies as provisions in entering the world of work.

In order for the implementation of industrial work practice programs to run optimally and provide additional experience for students, the institution should really prepare its students to have basic skills that are useful and make it easier for DU / DI to provide guidance and enrichment of knowledge when students carry out industrial work practice programs. Mapping DU / DI that is in accordance with the character of students and periodic and continuous monitoring affects the success of students in the 
industrial work practice program that they participate in. So that students gain experience to enter the real world of work with competency knowledge, skills and work ethic attitudes that have been well developed.

\section{REFERENCES}

Adams, N., Little, T. D., \& Ryan, R. M. (2017). Self-determination theory. Development of Self-Determination Through the Life-Course, 55(1), 47-54. https://doi.org/10.1007/978-94-024-1042-6_4

Almomen, R. K., Kaufman, D., Alotaibi, H., \& Al-rowais, N. A. (2016). Applying the ADDIE - Analysis, Design, Development, Implementation and Evaluation - Instructional Design Model to Continuing Professional Development for Primary Care Physicians in Saudi Arabia. August, 538-546.

Andriani, N., Suhendi, E., Samsudin, A., \& Ramalis, T. R. (2020). Identification of Creative Thinking Ability of Malay Ethnic Students in Archimedes Law with Rasch Analysis Model (RAM): A Case Study. Journal of Physics: Conference Series. https://doi.org/10.1088/1742-6596/1467/1/012050

Ardi, Z. (2019). An analysis of education principle implementation in an online counseling approach: a preliminary study based on analysis using the Rasch model. COUNS-EDU: The International Journal of Counseling and Education, 4(2), 59. https://doi.org/10.23916/0020190418720

Atkinson, G. (2015). Work-based learning and work-integrated learning: fostering engagement with employers.

Azwar, S. (2018). Realiabilitas dan Validitas, Yogyakarta: Pusataka Pelajar.

Bellová, R., Melicherčíková, D., \& Tomčík, P. (2018). Possible reasons for low scientific literacy of Slovak students in some natural science subjects. Research in Science and Technological Education. https://doi.org/10.1080/02635143.2017.1367656

Dwi Anugerah1, Daryati2, R. (2017). Evaluasi Pelaksanaan Program Prakerin berdasarkan Pedoman Prakerin Di SMKN 3 Depok Program Keahlian Batu Dan Beton. 6(1), 1-7.

Dwi Rahdiyanta. (2019). Kesiapan Berwirausaha Siswa SMK. 4(April), 54-63.

Ferguson, R. F. (2014). The 2013 Charles H. Thompson Lecture-Colloquium Presentation Elements of a 21st Century Movement for Excellence with Equity. The Journal of Negro Education, 83(2), 103-120. http://www.agi.harvard.edu/FergusonExcellencewithEquitySpring2014.pdf

Iriani, D. S., \& Soeharto, S. (2015). Evaluasi Pelaksanaan Praktik Kerja Industri Siswa Kompetensi Keahlian Jasa Boga SMK N 3 Purworejo. Jurnal Pendidikan Teknologi dan Kejuruan, 22(3), 274. https://doi.org/10.21831/jptk.v22i3.6835

Irwan Aferi, W. (2019). Evaluasi Implementasi Program Praktek Kerja Industri (PRAKERIN) Pada Kelas XI Jurusan Teknika Kapal Penangkap Ikan Di SMK Negeri 19 Padang. 775-782.

Muh. Nasir Malik dan Hasanah. (2019). Evaluasi praktik kerja industri sekolah menengah kejuruan.

Nugraha, D. (2019). Transformasi Sistem Revolusi Industri 4.0. September 2018.

Rohman, A., \& Ningsih, Y. E. (2018). Pendidikan Multikultural : Penguatan Identitas Nasional Di Era Revolusi Industri 4.0. UNWAHA Jombang, 1(September), 4450. http://ejournal.unwaha.ac.id/index.php/snami/article/view/261

Sampun Adam, Nastiti Rahayu, A. nur A. (2019). Strategi Implementasi Revitalisai SMK.

Skriner, L. C., Wolk, C. B., Stewart, R. E., Adams, D. R., Rubin, R. M., Evans, A. C., 
\& Beidas, R. S. (2017). Therapist and Organizational Factors Associated with Participation in Evidence-Based Practice Initiatives in a Large Urban PubliclyFunded Mental Health System. https://doi.org/10.1007/s11414-017-9552-0

Widiawati, L., Joyoatmojo, S., \& Sudiyanto. (2018). Higher order thinking skills as effect of problem based learning in the 21st century learning. International Journal of Multicultural and Multireligious Understanding, 5(3), 96-105.

Yusri Kamin, ., Cartledge, D., Mohd. Zolkifli Abd. Hamid, ., Mohamad Sukri Saud, ., Asnur Dahar Minghat, ., \& Mohd Hilmi Hamzah, . (2014). How Work-Based Learning In Community Colleges Help Students Work In Industry In Malaysia And Comply To The Standards Required. 10th Asian Academic Society for Vocational Education and Training (ASSVET) Conference pada 18-20 oktober 2014., November. https://doi.org/10.13140/2.1.4814.0488 